\title{
SOCIAL EDUCATION THROUGH DIGITAL LITERACY AMONG INDONESIAN FEMALE MUSLIM ACTIVISTS The Experience of Abdurrahman Wahid's Daughters
}

Evi Fatimatur Rusydiyah | UIN Sunan Ampel Surabaya - Indonesia evifatimatur@uinsby.ac.id

\begin{abstract}
This article analyses the experience of Indonesian women Muslim activists in conducting social education through digital literacy. It focuses on Twitter as the media of digital literacy they actively employ. Responses to tweets are assessed with Anderson's taxonomic indicators (namely remembering, understanding, applying, analyzing, evaluating, and creating) in order to know the cognitive level of society under the framework of social education. With regards to the notion of the Indonesian women Muslim activists, this article refers to four daughters of the late Abdurrahman Wahid, Alissa Qotrunnada, Zannuba Ariffah Chafsoh, Anita Hayatunnufus, and Inayah Wulandari, being known as social activists on religions, multiculturalism, equality, democracy, and human rights, particularly through their tweets. This paper argues that women Muslim activists play a key role in making use of digital media for leading the Indonesian Muslim community to become a critical society. Through the enhancement of the society's cognitive level, it further argues, those women Muslim activists have skillfully developed digital literacy-based social education for people's socio-political criticism.
\end{abstract}

Keywords: Digital literacy, muslim society, social education, social media, muslim female figures

\section{Introduction}

Information and communication technology (ICT) continues to develop every year. It makes it easy for people, including the Indonesian Muslim society, to get the information they needed. Consequently, data and information have become a valuable commodity nowadays. Their flow is highly influenced by the development of information technology. 
One of the impacts of the development of ICT is the emergence of social media. It is used to spread information and social issues. The high intensity of the conversation in social media made people divided into two types. The first type is new users of social media who then leave comments and the second type is active users who frequently leave comments. While the former are people that make comments in a normative way, the latter are people who have a critical attitude and are dare to express their ideas openly. Therefore, the strengthening of digital literacy is so significant in this era so that people can adapt well to social changes. ${ }^{1}$

The process of growing, influencing, developing and shaping one's social attitude in a community as above is a process of social education. ${ }^{2}$ Social education has a role in the effort to guide and build a community's potential optimally so that it can answer the demands and needs of the community. ${ }^{3}$ Likewise, social education has a role of educating, guiding and forming responsible individuals who become the drivers towards progress and change in the social lives. From the elaboration process of communication, the social changes in a society will be in line with their wishes. In Thomas Aquinas' educational philosophy, the community is the voice of God. A happy education whether for the individual or for social will be more readily accepted. ${ }^{4}$

The development of technology makes the process of social education very possible through digital literacy. Digital literacy is knowledge and skills to use digital media, communication tools or networks in finding, evaluating, using, providing information, and using it in health, wise, intelligent, accurate, precise, and law-abiding manner to foster communication and interaction in everyday life.

Society is increasingly dependent on the digital world. A research conducted by Sharima et al. ${ }^{5}$ finds that the digital literacy skills of

1 Julian McDougall, Mark Readman, and Philip Wilkinson, "The Uses of (Digital) Literacy Learning," Media and Technology, 43, 3 (2018), pp. 263-79.

2 Sergei I. Belentsov and others, "The Organization of Social Education in Paul Natorp's Creativity," European Journal of Contemporary Education, 6, 4 (2017), pp. 656-63.

3 Richard Neumann, "American Democracy in Distress: The Failure of Social Education," Journal of Social Science Education, 16, 1 (2017), pp. 5-16.

4 Dennis M. Doyle, "Thomas Aquinas: Integrating Faith and Reason in the Catholic School," Catholic Education: A Journal of Inquiry and Practice, 10, 3 (2007), pp. 343-356.

5 As quoted by Tenku Putri Norishah Tenku Shariman, Norizan Abdul Razak, and Nor Fariza Mohd. Noor, "Digital Literacy Competence for Academic Needs: An 
university students in Malaysia depend on two aspects, namely the ability to speak English and multimodal design of digital content. The lack of these two aspects became obstacles when they dealt with digital tools. However, these obstacles did not dampen their interest in using digital tools. This context reinforces Prensky's opinion, stating that Malaysian society was mostly digital natives. ${ }^{6}$ Besides, a research conducted by Traxler maintains that refugee communities in Palestine need digital literacy. Therefore, access to meet them is necessary. ${ }^{7}$ Strengthening digital literacy aims to educate the public so that they can utilize technology wisely. ${ }^{8}$ Digital literacy is the ability to understand various information obtained from sources accessed from the internet, computers, and other software. ${ }^{9}$ One of the means of digital literacy is the use of social media such as Twitter.

Twitter is one of the digital literacy tools. Twitter was chosen in this study because it is one of the top ranks of social media that is demanded by the community, including the Indonesian Muslim community. ${ }^{10}$ The number of Twitter users is increasing every year in Indonesia. According to Ardiansyah, Twitter's Country Head of Indonesia and Malaysia, the average growth of Twitter users in Indonesia in the fourth quarter of 2018 reached $41 \%$, while the global growth only reached $9 \% .{ }^{11}$ Based on the data stated in Statista, the number of Twitter users in Indonesia in the period of 2014-2019 has continued to increase every year. As recorded in 2019, the number of

Analysis of Malaysian Students in Three Universities," Procedia - Social and Behavioral Sciences, 69 (2012), pp. 1489-96.

6 Marc Prensky, Digital Natives, Digital Immigrants. In on the Horizon (Lincoln: NCB University Press, 2001).

7 John Traxler, "Digital Literacy: A Palestinian Refugee Perspective," Research in Learning Technology, 26 (2018), pp. 1-21.

8 Gilster, Digital Literacy (New York: Wiley, 1997), p. 72.

9 Ibid.

10 Ahmad Fathan Hidayatullah, "Twitter Sebagai Media Dakwah," Teknoin, 22, 1 (2016), pp. 38-43.

11 Charlie M. Sianipar, "Jumlah Pengguna Twitter Indonesia Naik Pesat" https://www.tagar.id/jumlah-pengguna-twitter-indonesia-naik-pesat (accessed on 3 October 2019). 
Twitter users reached 22.8 million. ${ }^{12}$ Twitter has become a familiar social media in Indonesia, in which most of the users are Muslims.

Thus, this article focuses on how the experience of Indonesian female Muslim activists in conducting social education through digital literacy. Furthermore, this research focuses on Gus Dur's daughters' tweets because they are quite influential in society. ${ }^{13}$ This is because of their social activities within their communities and the fact that they are daughters of the late Abdurrahman Wahid (1940-2009), commonly called as Gus Dur, the prominent religious leader and the fourth President of Indonesia. Their character has also been shaped by the upbringing of their mother, Sinta Nuriyah Wahid (b. 1948), who is also an activist, intellectual and religious leader. ${ }^{14}$ As Gus Dur's daughters, they are very responsible and committed to providing social education to all Indonesian people. Likewise, as individuals, they actively fight for democracy, equality, human rights, and multiculturalism. Therefore, their comments have an impact on shaping public opinion.

This research is conducted qualitatively by identifying tweets from Gus Dur's daughters about social education. The data is retrieved through crawling tweets from Twitter. Therefore, the data source of this study is the top tweets during 2019. The re-tweets data are analyzed based on Anderson's taxonomy to figure out the level of public knowledge.

\section{Social Education Discourse}

Paul Gerhard Natorp first introduced the discourse on social education in his work "Social Pedagogics" in 1911.15 Natorp asked how leaders can carry out systems, cultural changes, and historicalcomparative in social education. In his work, the discussion in question is how the relationship between education and society that drives the formation of social pedagogy. Community is the main requirement for education. Thus the debate about social education has become a

12 Statista, "Number of Twitter Users in Indonesia from 2014 to 2019 (in Millions)" https://www.statista.com/statistics/490548/twitter-users-indonesia/ (accessed on 3 October 2019).

13 Reza Pamungkas, "Keluarga Gus Dur Masih Sangat Berpengaruh" https://www.kompasiana.com/pinpol/5b9b6eaa677ffb65cc7d08f6/keluarga-gus-durmasih-sangat-berpengaruh?page $=$ all (accessed on 4 December 2019).

14 Ibid.

15 Belentsov and others, "The Organization of Social Education," p. 8. 
strategic issue in terms of laying the foundation for the idea of social change. ${ }^{16}$ Social change means a shift that is better following the particular value order of individuals and society. Thus the role of change agents becomes essential. The agents of change can be political figures, educational figures, government figures, or famous people in specific communities. ${ }^{17}$

The public trust them because of their knowledge or influence in society. Social education becomes a media and a place to instil state or society ideology or bones that support the social framework of society ${ }^{18}$. It is in line with the understanding of education in general, that education is a conscious effort of a person or group of individuals to guide and develop the potential of the community optimally so that they can play a role following the demands and needs of the community's environment. ${ }^{19}$ In other words, social education is an attempt to influence and develop the social attitudes of a community group. ${ }^{20}$ Social education plays an essential role in fostering life with its environment. Social education is a form of views and behavioural manifestations of individuals in carrying out their rights and obligations, mental balance, social criticism and political activities in social life. Thus, social education becomes an important subject. Every level of society must accept it.

Belentsov et al. are not the only ones who conduct the study on social education. ${ }^{21}$ There are other scholars such as Neumann, ${ }^{22}$ Moss and Petrie, ${ }^{23}$ Duisenbayev et al., ${ }^{24}$ and Barona and Carrió. ${ }^{25}$ The

16 Neumann, "American Democracy in Distress," p. 7.

17 Peter Moss and Pat Petrie, "Education and Social Pedagogy: What Relationship ?," London Review of Education, 17, 3 (2019), pp. 393-405.

18 Belentsov and others, "The Organization of Social Education."

19 Neumann, "American Democracy in Distress."

20 Moss and Pat Petrie, "Education and Social Pedagogy," p. 12.

21 Belentsov and others, "The Organization of Social Education."

22 Neumann, "American Democracy in Distress."

23 Moss and Pat Petrie, "Education and Social Pedagogy."

24 Abay K. Duisenbayev and others, "Study of Problems of Individual's Social Education," International Journal of Environmental and Science Education, 11, 15 (2016), pp. 7899-7905.

25 Eduardo Barona and Elena Carrió, "The Need of Education in Respect for Animals (ERA) as a Subject of the Social Education Degree at the University: An Overview Focused on Spain," Journal of Social Science Education, 15, 3 (2016), pp. 40-46. 
survey of Belentsov et al. discusses how a famous German philosopher, Paul Gerhard Natorp (1854-1924), introduced social education, which had a significant impact on current education trends. For him, education is not only the responsibility of schools but also the responsibility of the community. Natorp is an essential figure in the foundation of non-formal education. ${ }^{26}$ Likewise, Neumann proposes a similar premise. He found that social education programs in the United States did not adequately prepare young people for political participation in America. Therefore this deficiency has contributed significantly to the pressures in American democracy. Neumann's research is interesting because it argues that the United States still failed to prepare young people for democracy through social education..$^{27}$ Another study was conducted by Moss and Petrie. They found that the relationship between social education and the meaning of education, in general, depends on the purpose attached to the conception of education itself. Children and adolescents who are still in school have a different orientation of the study. Children and adolescents focus on their learning achievement, while adults focus on how to be prosperous.

In addition, Duisenbayev et al. describe that social education has an influence on personal development that is comprehensive in the conditions of the multicultural world. 28 These theses were strengthened by Barona and Carrió in their research. They highlighted a serious education gap associated with animals. In this study, they use the Education with Respect for Animals (ERA) instrument. The instrument works for the social education of students in Spain. The findings of this study indicate that the application of the social education curriculum at the university affects the concern of students in loving animals. ${ }^{29}$

To deliver social education needs media, both direct and indirect media. In using the direct media, the public is directly involved, for instance, through discussion, training, open debate, workshops and so forth. Meanwhile, indirect media is used for delivering social education without involving citizens directly. It is usually carried out en masse

\footnotetext{
26 Belentsov and others, "The Organization of Social Education."

27 Neumann, "American Democracy in Distress."

28 Duisenbayev and others, "Study of Problems of Individual's Social Education," p. 9.

29 Barona and Carrió, "The Need of Education," p. 6.
} 
that aims to raise awareness of citizens and provide valuable information to the general public regarding specific public issues. ${ }^{30}$ In today's digital era, the use of indirect media in delivering social education is more often used, namely by utilizing general information and communication media. Social media, as a part of digital media, is commonly used recently. Indonesian people usually refer to the tweets of Gus Dur's daughters as a medium to deliver social education.

The character of Gus Dur and his wife is passed down to their daughters. ${ }^{31}$ Besides the strong character of Gus Dur, his wife also played a significant role in educating her daughters through the process of habituation and role models at home. ${ }^{32}$ The educational process carried out by Gus Dur and his wife shaped the attitudes and character of the daughters as tough individuals. This toughness led their daughters to become activists of Indonesian Muslim women. They actively engage in various social organizations through which they influence the surrounding community. ${ }^{33}$ It is in line with Paul Natorp's opinion that a public figure can change the community's perception because they know him/ her. ${ }^{34}$

\section{Digital Literacy}

In the last few years, the government has campaigned intensively for digital literacy, and it is evidenced in the development of various digital literacy movements that continue to develop in communities. Not only has the government campaigned for digital literacy actively, but also some institutions such as academicians and non-profit organizations have made the same efforts. ${ }^{35}$ The concept of digital

\footnotetext{
30 Marianna Papastephanou, "Political Education in Times of Political Apathy and Extreme Political Pathos as Global Ways of Life," Educational Studies in Japan: International Yearbook, 13 (2019), pp. 81-95.

31 Rizal Abdul Aziz Hadi Rizki, Peran K.H. Abdurrabman Wabid / Gus Dur pada Masa Reformasi (1998-2001), (Bandung: UIN Sunan Gunung Djati, 2017).

32 Asfa Widiyanto, "Female Religious Authority, Religious Minority and the Ahmadiyya: The Activism of Sinta Nuriyah Wahid," Journal of Indonesian Islam, 9, 1 (2015), pp. 1-24.

33 Ibid.

34 Belentsov and others, "The Organization of Social Education," p. 6.

35 Novi Kurnia and Santi Indra Astuti, "Peta Gerakan Literasi Digital di Indonesia: Studi tentang Pelaku, Ragam Kegiatan, Kelompok Sasaran dan Mitra yang Dilakukan oleh Japelidi," Informasi Kajian Ilmu Komunikasi, 47, 2 (2017), pp. 149-66.
} 
literacy comes from a variety of reasonably long processes. ${ }^{36}$ The idea continues to evolve and transform from time to time. In the beginning, the concept of digital literacy was born from media literacy, which initiated the importance of being critical of television media. The idea continues to grow while the internet and all kinds of other communication technologies emerged.

The concept continues to be echoed so that it develops and transforms into information literacy because the use of the internet provides broad access to information. ${ }^{37}$ Along with the times, the concept of information literacy is considered insufficient to resolve various problems and controversies that lately continue to circulate. Therefore, the idea of digital literacy was born. Digital literacy is an individual's skill in using media wisely so that s/he can have useful and relevant information management skills. ${ }^{38}$ Thus, the concept of digital literacy does not stand alone. It is interrelated with other literacy concepts. This research will be more focused on digital literacy because the emphasis of media literacy is more on the mastery of digital tools. Meanwhile, information literacy only limits the ability of individuals to understand and to select information. However, digital literacy has a focus on digital platforms that place mediation as a significant issue.

Digital literacy first appeared in 1997 by Gilster. Gilster explained that the concept of digital literacy is the ability to understand and use various digital information tools. ${ }^{39}$ Thus, digital literacy is not just the ability to read data. However, it is a critical thinking ability which is urgent for evaluating the information found in digital media. According to Goodfellow, digital literacy ability is a multiliteracies skill that must be possessed by every individual. ${ }^{40}$ This ability is a form of mastery of the capabilities, awareness and attitudes of individuals in utilizing various digital devices to communicate and apply them in real everyday life. Digital literacy is the ability to understand the

\footnotetext{
36 W. James Potter, "The State of Media Literacy," Journal of Broadcasting \& Electronic Media, 54, 4 (2010), pp. 675-696.

37 David Buckingham, "Defining Digital Literacy: What Do Young People Need to Know about Digital Media?," Nordic Journal of Digital Literacy, 4 (2015), pp. 21-34.

38 Ibid.

39 Gilster, Digital Literacy.

40 Robin Goodfellow, "Literacy, Literacies, and the Digital in Higher Education," Teaching in Higher Education, 16, 1 (2011), pp. 131-144.
} 
information in a digital format consisting of words, images, videos or sound recordings. ${ }^{41}$

Media for digital literacy consists of several types. One of them is social media. Social media is a medium that is used by individuals with one another to socialize with each other online. They can interact freely without a time limit. According to a research on social media management platform, Hootsuite and social marketing agency We Are Social, said that the number of internet users in Indonesia had reached 175.4 million people, while the total population of Indonesia is around 272.1 million. Compared to 2019, the number of internet users in Indonesia increased by about 17 per cent or 25 million users. Internet users in 2020 are shown in Figure 1.

Figure 1. Indonesian Internet Users in $2020^{42}$

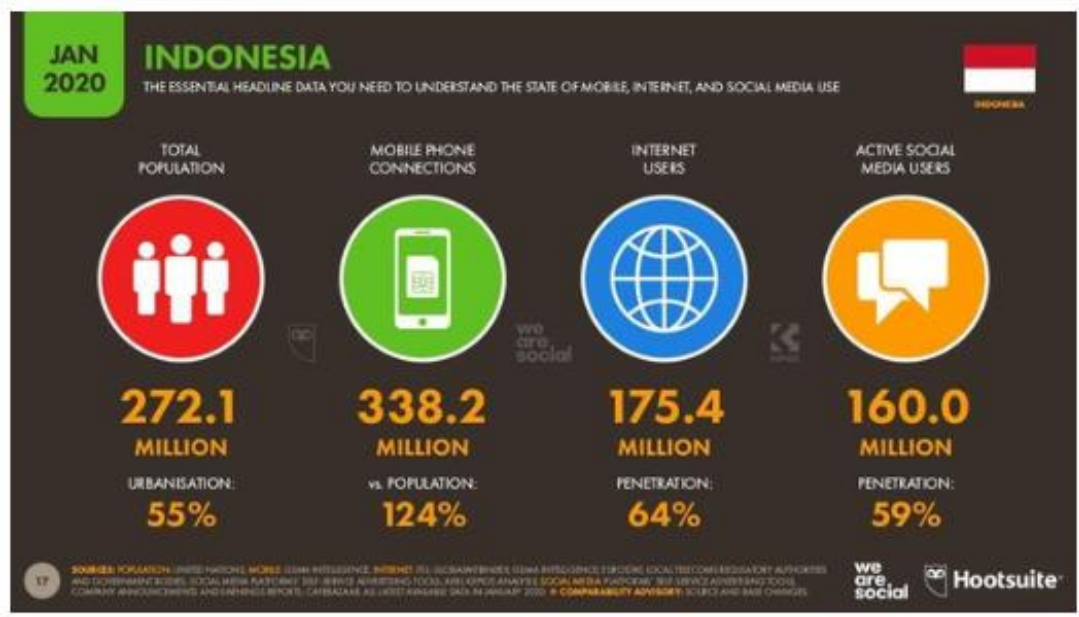

Based on Figure 1, it shows that out of 175.4 million internet users in Indonesia, 160 million are active social users. It indicates that Indonesian people are very busy in interacting using social media. ${ }^{43}$ The substantial activity shown by the graph demonstrates that social media users in Indonesia are in the very high category. Thus, awareness

41 Richard A. Lanham, "Digital Literacy," Scientific American, 273, 3 (1995), pp. 198-200.

42 Agus Tri Haryanto, "Riset: Ada 175,2 Juta Pengguna Internet di Indonesia," Detikinet, 2020. https://inet.detik.com/cyberlife/d-4907674/riset-ada-1752-jutapengguna-internet-di-indonesia (accessed 4 March 2020).

43 Ibid. 
of using the media properly has the opportunity to spread positive issues related to social education. ${ }^{44}$ It is also applied to Gus Dur's daughters, who are part of active social media users of Twitter. The Gusdurian community, a community engaged in implementing Gus Dur's ideas, knows Gus Dur's daughters well as Muslim women leaders in Indonesia. ${ }^{45}$ As Muslim women leaders in Indonesia, they are influential in Indonesia. What they convey in their tweet on Twitter will shape people's perspectives. Therefore they have the potential to make changes to the Indonesian nation for the better through social education by using Twitter as a digital literacy medium. ${ }^{46}$

\section{Social Media as Social Education Resource}

Social media is overgrowing with the growth and ease of access to information supported by the power of communication technology. In this era, social media is very supportive of any aspect. Knowledge in any form can be distributed quickly and freely because of the role of social media itself. Free information can be disseminated rapidly to make people understand the objectives of social media users.

Social media is also a messenger for social education issues. Therefore, social media becomes an essential element that can influence relationships between social creatures. ${ }^{47}$ The role of social media in the context of spreading social education issues on Twitter can be seen in the communication between Twitter account holders and those who leave responses. The conversation is an intentional or unintentional means of education, and systematically forming socially aware individuals who can become socially and morally responsible actors in achieving social goals. ${ }^{48}$

Social education in the Indonesian context has functioned as a process of conveying the nation's social culture, encompassing social ideals and operational norms of a social organization system based on

\footnotetext{
${ }^{44}$ Lanham, "Digital Literacy," p. 12

45 Greg Barton, Biografi Gus Dur; The Authorized Biography of Abdurrabman Wabid (Yogyakarta: LKiS, 2003).

46 Ibid.

47 Apriadi Tamburaka, Literasi Media: Cerdas Bermedia Khalayak Media Massa (Jakarta: Rajawali Press, 2013).

48 K. Kartono, Pendidikan Politik Sebagai Bagian dari Pendidikan Orang Dewasa (Bandung: Mandar Maju, 2009).
} 
Pancasila values. ${ }^{49}$ Thus, the purpose of social education is to increase public knowledge so that they can participate optimally in the social network following with the understanding of popular sovereignty as the noble ideals of the Indonesian nation. ${ }^{50}$ The results of that appreciation will give birth to attitudes, knowledge, and new social behaviour that supports the ideal social system. Thus, at the same time, a new social culture is born. Continuous social education learning is urgent, given the problems in the social realm are very complex, multifaceted, and changing. ${ }^{51}$

Social education carried out by Gus Dur's four daughters in the context of this research is an educational effort to the community through their tweets on Twitter in shaping public opinion related to Indonesian social values as the ideals of the nation. There are five issues of the social education contained in Gus Dur's daughters' tweets. These issues are religions, multiculturalism, equality, democracy, and human rights. The exploration of these issues is discussed in the section of the description of Gus Dur's daughters' activities.

The tweets of the four Gus Dur's daughters contain much value, describing the Indonesian plurality. These messages are Gus Dur's teachings as the father of the nation. Gus Dur is known as a figure who laid the democratic values in Indonesia. ${ }^{2}$ The tweets of his four daughters resemble these values. Gus Dur's daughters are very active in the issue of human rights through the institutions they established. The Wahid Foundation they founded is concerned about humanitarian issues. ${ }^{53}$ Inayah Wahid also founded the NGO named Positive Movement (PM) in 2006.

49 Werpen Wenda, "Tingkat Kesadaran Politik Pemilih Pemula dalam Pemilihan Umum Bupati dan Wakil Bupati Kabupaten Lanny Jaya Provinsi Papua; Suatu Studi di Distrik Pirime," Jurnal Politico, 1, 3 (2013).

50 Rusadi Kantaprawira, Sistem Politik Indonesia, Suatu Mode Pengantar Edisi Revisi (Bandung: Sinar baru Algensindo, 2004).

51 Ahmad Anis Abdullah and Suhartini, "Meningkatkan Kemampuan Berpikir Kritis Melalui Pembelajaran Statistika Berbasis Pendidikan Politik di Lingkungan Sekolah," Jurnal Gantang, 2, 1 (2017), pp. 1-9.

52 Abdurrahman Wahid, Prisma Pemikiran Gus Dur (Yogyakarta: LKiS, 1999).

53 Wahid Instutute, "Tentang The Wahid Institute" http://www.wahidinstitute.org/wi-id/ (accessed on 15 October 2019). 
Social education, as above, can now be facilitated by social media. Social media has a significant role in shaping public opinion, and Twitter is no exception. Twitter is chosen because it is the most potent idea delivery tool at the moment. ${ }^{54}$ Internet users in Indonesia are 143.26 million people or around $54.7 \%$ of the total population. ${ }^{55}$ From the data, $48.2 \%$ of those using the internet are using Twitter. Currently, Indonesia is also ranked sixth in the world as the country with the highest number of internet users. ${ }^{56}$ However, in general, these internet users do not have excellent literacy capabilities. ${ }^{57}$ The data from the Director or International Information Services, Directorate of Information and Public Communication (IKP) show that Twitter and Facebook are the most widely used social media in Indonesia. ${ }^{58}$

In 2019, Indonesia was also ranked fifth as the most significant Twitter user in the world after the USA, Brazil, Japan, and the United Kingdom. ${ }^{59}$ The Global Digital Overview also reports the data. ${ }^{60}$ The rapid use of social media can be seen from Global Index data. The data show that Indonesian internet users are using various social media, such as Twitter, Facebook, Google+, Path, Linkedin, YouTube and Instagram. ${ }^{61}$ Juditha's finding confirms the data. Juditha found

54 Liputan6, "Tweet Kemenangan Obama Jadi Tweet Terpopuler" https://www.liputan6.com/tekno/read/451332/tweet-kemenangan-obama-jadi-tweetterpopuler (accessed on 12 October 2019).

55 Anang Sugeng Cahyono, "Pengaruh Media Sosial terhadap Perubahan Sosial Masyarakat di Indonesia," Publiciana, 9, 1 (2016), pp. 140-57.

56 Kementerian Komunikasi dan Informatika Republik Indonesia, "Pengguna Internet Indonesia Nomor Enam Dunia" https://kominfo.go.id/index.php/content/detail/4286/Pengguna+Internet+Indonesia+Nomor+Enam+Dunia/0/sorotan_media (accessed on 23 October 2019).

57 Kurnia and Astuti, "Peta Gerakan Literasi Digital di Indonesia."

58 Kementrian Komunikasi dan Informatika Republik Indonesia, "Kominfo: Pengguna Internet Di Indonesia 63 Juta Orang" https://www.kominfo.go.id/content/detail/3415/kominfo-pengguna-internet-di-indonesia-63-juta-orang/0/berita_satker (accessed on 3 October 2019).

59 Ibid.

60 Data Portal, "Digital 2019: Global Digital Overview" https://datareportal.com/reports/digital-2019-global-digital-overview (accessed 3 October 2019).

61 Jeko I.R., "Pengguna Internet Indonesia Kuasai Media Sosial di 2015" https://www.liputan6.com/tekno/read/2164377/pengguna-internet-indonesia-kuasaimedia-sosial-di-2015 (accessed on 3 October 2019). 
that Indonesians tend to use Twitter when discussing a popular topic in Indonesia. ${ }^{62}$

One effort that can be used to analyze the level of understanding of digital literacy in the community is the metacognition approach. Metacognition is the ability to control the objects of cognition in any cognitive knowledge or activity that takes them as its object to regulate all aspects of any cognitive business. ${ }^{63}$ Metacognitive can be in the form of memory, understanding, application, analysis, evaluation, and creation. ${ }^{64}$

Some related researches on digital literacy have been conducted. Among the relevant inquiry was the study conducted by Salma Jan, who analyzes the relationship between students' digital literacy and their attitudes toward the use of ICT. Furthermore, a research conducted by Nia Kurniawati et al. analyzes the benefits of digital literacy in an EFL (English as a Foreign Language) class of two generations (digital immigrants and digital natives) and student's responses to the use of digital media in English classrooms in Indonesia. ${ }^{65}$

Furthermore, a study conducted by Alamsyah (2018) described digital literacy patterns among Sriwijaya University lecturers and their contribution to the implementation of e-learning. ${ }^{66}$ Further research was conducted by Piatip Phuapan et al. (2016), who analyzed the digital literacy skill of the senior students in a university in Thailand. ${ }^{67}$ This study seeks to know which digital literacy skills are the most significant skill for information technology use. These skills consist of

62 Christiany Juditha, "Fenomena Trending Topic di Twitter: Analisis Wacana Twit \#Savehajilulung," Jurnal Penelitian Komunikasi dan Pembangunan, 16, 2 (2018), pp. 138154.

63 John H. Flavell, "Theory of Mind Development: Retrospect and Prospect," MerrillPalmer Quarterly, 50, 3 (2004), pp. 274-290.

${ }^{64}$ Lorin W. Anderson and others, A Taxonomy for Learning, Teaching, and Assessing: A Revision of Bloom's Taxonomy of Educational Objectives (New York: Longman, 2013).

${ }^{65} \mathrm{Nia}$ Kurniawati, Elis Homsini Maolida, and Agung Ginanjar Anjaniputra, "The Praxis of Digital Literacy in the EFL Classroom: Digital-Immigrant vs Digital-Native Teacher," Indonesian Journal of Applied Linguistics, 8, 1 (2018), pp. 28-37.

66 Alamsyah Alamsyah, "Digital Literacy among Sriwijaya University Lecturers," Informasi, 47, 2 (2017), p. 243.

67 Piatip Phuapan, Chantana Viriyavejakul, and Paitoon Pimdee, "An Analysis of Digital Literacy Skills among Thai University Seniors," International Journal of Emerging Technologies in Learning, 11, 3 (2016), pp. 24-31. 
accessing, managing, integrating, evaluating, creating, and communicating information to retain public knowledge. Furthermore, a research conducted by Shariman et al. (2012) analyzed digital literacy competencies for the academic needs of Malaysian students who studied in several Malaysian universities. ${ }^{68}$ Some digital media content in the form of text, sound, animation and videos will be taken and then will be analyzed using thematic analysis to identify themes and concepts throughout the data set as well as identifying recurring patterns of meaning.

Based on the current social condition, it is essential to give enough attention to the reconstruction of social education to strengthen digital literacy. A different level of understanding of information makes the information obtained is not always in line with what the disseminator was trying to reach. Therefore, analyzing the cognitive process of community's understanding is needed to be carried out regarding social education in Twitter distributed by Muslim scholars. The result of the analysis clustered into six sections based on Anderson's taxonomic level which is the revision of Bloom's taxonomic level.

Bloom's taxonomy consists of knowledge, understanding, application, analysis, synthesis, and evaluation. In 2001, Anderson revised the six classifications of Bloom's taxonomy and defined the 6 clusters as remembering, understanding, application, analyzing, evaluating, and creating. Remembering is the ability to seek and find knowledge from long-term memory. Understanding is the ability to construct the meaning of messages. Application is the ability to implement or use a procedure in an existing situation. Analyzing is the ability to break down the material into its constituent parts and determine how these parts are related to each other and their whole structure or purpose. Evaluation is the ability to make judgments following criteria or standards. Creating is the ability to arrange elements together to form a coherent or functional whole, or in other words, reorganize the parts into a new pattern or structure ${ }^{69}$.

The six abilities are a person's ability in the educational process, including in social education. The four daughters of Gus Dur as Muslim female activists have the potential to provide knowledge to

68 Shariman, Razak, and Mohd. Noor, "Digital Literacy Competence for Academic Needs," p. 5.

69 Anderson LW. and others, A Taxonomy for Learning, Teaching, and Assessing: A Revision of Bloom's Taxonomy of Educational Objectives (New York: Longman, 2001). 
society. The people's cognitive abilities in responding to the knowledge conveyed by Gus Dur's four daughters can be mapped through these six taxonomies. The question is whether people react to this knowledge by only commenting on the remembering level or on the understanding, application, analyzing, evaluating, or creating levels. If the community only says on the remembering level, it shows that the knowledge possessed by the community is at the lower-order ranking skill level, but if it is shifted to the next level, the community is at a higher-order ranking skill. The level of analysis is the beginning of high-order thinking skills. ${ }^{70}$ High order thinking ability is a metacognitive skill. ${ }^{71}$

The pattern of knowledge distribution of Gus Dur's four daughters as Muslim women activists via Twitter, then the community responds well at certain levels, is a sign that society is literate in using social media as digital literacy media. ${ }^{72}$ In other words, the public can intelligently utilize Twitter as social media to make not only negative responses but also positive responses that are appropriate to Anderson's taxonomy levels. ${ }^{73}$ Thus, digital literacy, as a form of awareness, attitude, and one's ability to use digital tools, can create critical new skills, and those are the findings of this study. ${ }^{74}$

\section{The Experiences of Indonesian Female Muslim Activists}

The increase in Twitter users affects female Muslim figures who have essential roles in shaping people's knowledge. ${ }^{75}$ The female characters in this study refer to the four daughters of Gus Dur. They are Alissa Qotrunnada (b. 1973), Zannuba Ariffah Chafsoh (b. 1974), Anita Hayatunnufus (b. 1978), and Inayah Wulandari (b. 1982). They

70 Wail Minwer, Al Rabadi, and Rifqa Khleif Salem, "The Level of High-Order Thinking and Its Relation to Quality of Life among Students at Ajloun University College," International Education Studies, 11, 6 (2018), pp. 8-21.

71 Ibid.

72 Ezgi Pelin Yildiz, "Opinions of Academicians on Digital Literacy: A Phenomenology Study," Cypriot Journal of Educational Sciences (CJES), 15, 3 (2020), pp. 469-478.

73 Mandy Johnson and others, "Twitter: a Tool for Communities of Practice," SRATE Journal, 28, 1 (2019), pp. 61-75.

${ }^{74}$ Mehmet Haluk Sivrikaya, "An Analysis on Digital Literacy Level of Faculty of Sports Science Students," Asian Journal of Education and Training, 6, 2 (2020), pp. 117-21.

75 Pamungkas, "Keluarga Gus Dur," p. 9. 
have a lot of Twitter followers. Tweeter of @ AlissaWahid has 371,900 thousand followers. Tweeter of @yennywahid has 214,000 thousand followers. Tweeter of @anita_wahid has 47,700 thousand followers. Tweeter of Inayah Wulandari@inayawahid has 39,700 thousand followers.

With so many followers, they have the potential to educate people socially. Gus Dur's character can inspire his daughters in commenting and giving an opinion to their followers in the context of human rights, democracy, multiculturalism, and openness as part of social education in Indonesia. ${ }^{76}$ In the next section, the tweets of the four daughters of Gus Dur will be mapped and will be divided into three clusters, namely social issues, religious issues, and unknown/others.

\section{Alissa Qotrunnada and Multicultural Movement}

Alissa Qotrunnada, commonly known as Alissa, is the first daughter of Gus Dur. She holds a Master of Psychology from Universitas Gajah Mada (UGM). As a Muslim influencer who is engaged in various areas such as social, cultural, and democracy issues. Currently, besides active in promoting tolerance and multicultural issues, she is also actively campaigning for interfaith dialogue. Alissa serves as the coordinator of the Indonesian Gusdurian Network Organization. ${ }^{77}$ The organization functions to gather individuals and communities to preserve Gus Dur's legacy through a variety of strategical works. ${ }^{78}$

Besides, Alissa is active in the Nahdlatul Ulama (NU) organization. She serves as the secretary of the Family Welfare Agency of NU (Lembaga Kemaslahatan Keluarga NU/LKKNU). ${ }^{79}$ She is responsible for promoting good, reliable and moderate Muslim family models. Alissa is also a Muslim scholar who has a myriad of achievements.

\footnotetext{
76 Muharir, "Arkeologi Pemikiran Pendidikan Islam (Studi Pemikiran Pendidikan Islam Abdurrahman Wahid)," Jurnal Al-Muta'aliyah STAI Darul Kamal NW Kembang Kerang, 1, 1 (2017), p. 25-52.

77 Nunung Dwi Nugroho, Gerakan Gusdurian sebagai Epistemic Community (Yogyakarta: Universitas Gajah Mada, 2013).

78 Kampung Gusdurian, "Jaringan Gusdurian" http://www.gusdurian.net/id/jaringan-gusdurian/ (accessed on 22 October 2019).

79 NU Online, "Susunan Lengkap Pengurus LKKNU 2015-2020" https://www.nu.or.id/post/read/62263/susunan-lengkap-pengurus-lkknu-2015-2020 (accessed on 22 October 2019).
} 
Because of her persistence in fostering tolerance and multiculturalism, she gets trusted to be a Civil Society Ambassador for Sustainable Development Goals in Indonesia. ${ }^{80}$ She was also awarded the shineOn award in 2015 from the Good Housekeeping Indonesia magazine. In 2016, she was awarded the Women Award from the Indonesia Marketing Week.

Since she is involved in various works and that she has hundreds of thousands of followers, Alissa's tweets certainly have a unique appeal for netizen. Alissa's conversation map in her Twitter account can be shown in the following chart:

Figure 2. Alissa Wahid's Tweets Conversation Map

\section{(a)alissawahid Tweets Mapping}
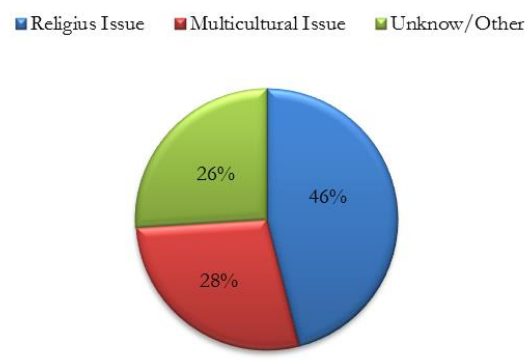

Based on Figure 2, religious issues dominate in Alissa Wahid's tweets $(46 \%)$ topic. This topic is in line with Gus Dur's family backgrounds, which strongly connect with Islamic boarding school. ${ }^{81}$ The second most discussed topic was the Multicultural Movement by $28 \%$. Alissa Wahid is also active in spreading the idea of tolerance and multiculturalism as the basis of education. ${ }^{82}$ Her concept is also the trademark of his father..$^{83}$ Alissa directly involves as a social actor, and she influences society for tolerance and multiculturalism issues. ${ }^{84}$

80 Mickael B. Hoelman and others, Sustainable Development Goals-SDGs; Panduan untuk Pemerintah Daerah (Kota dan Kabupaten) dan Pemangku Kepentingan Daerah (Jakarta: Infid, 2016).

81 Abdurrahman Wahid, Menggerakkan Tradisi: Esai-Esai Pesantren (Yogyakarta: LKiS Yogyakarta, 2001).

82 Barton, Biografi Gus Dur, p. 16.

83 Ibid.

84 Andyka Miftakhul Farid, Implikatur-Implikatur Percakapan dalam Wacana Humor Gus Dur (Surakarta: Universitas Sebelas Maret, 2012). 
Based on the chart, $26 \%$ of her tweets were on various topics. They were about greetings, joking with followers, and many more. It also shows Alissa's personality that is open and humorous. Alisa also imitates his father, who often delivers jokes in society, both in writing and orally. ${ }^{85}$ Based on the chart, Alissa's tweets on social education are exciting. This study took one of her top tweets on this topic. Some topics are of great interest to Alissa in terms of conveying her social education messages, namely religious issues and multicultural issues.

Alissa's empathetic attitude toward injustice issues appears in some of her top tweets. Among her top tweets on social education were about security forces who asked for help over the riot in South Jakarta Police Station. This tweet was re-tweeted 15,474 times, and 20,596 Twitter accounts like them. Of the 15,474 re-tweets, the result showed an in-depth response. Most of them support the tweet as they felt sorry for the security forces. Other people criticized and analyzed the background of the incident. As a female Muslim activist, she can encourage society to be emphatic about different cultures.

\section{Zannuba Ariffah Chafsoh and Wahid Foundation}

Gus Dur's second daughter is Zannuba Ariffah Chafsoh, commonly known as Yenny Wahid. Yenny Wahid is a Muslim woman activist and an Indonesian democracy fighter who currently serves as the founder and the director of the Wahid Foundation. Wahid Foundation was established to ground humanitarian vision of Gus Dur on tolerance, diversity in Indonesian society, improvement of the welfare of the poor, democracy, justice, and expansion of peace and non-violence values in Indonesia and throughout the world. ${ }^{86}$ Aside from being the director of Wahid Foundation, Yenny Wahid was a correspondent for some Australian newspapers in 1997 and 1999, The Sydney Morning Herald and The Age (Melbourne). ${ }^{87}$

Yenny Wahid is also a scholar and politician who is active in fighting for democracy. When his father becomes the $4^{\text {th }}$ president of Indonesia, she was the president's specialized staff in the field of social

\footnotetext{
85 Ibid.

86 Wahid Foundation, "Tentang Wahid Foundation" http://wahidfoundation.org/index.php/page/index/About-Us (accessed on 22 October 2019).

87 "Profil Zannuba Ariffah Chafsoh Rahman Wahid" https://m.merdeka.com/zannuba-ariffah-chafsoh-rahman-wahid/profil/ (accessed on 22 October 2019).
} 
communication. ${ }^{88}$ Moreover, between 2005 and 2008, she served as the secretary-general of Partai Kebangkitan Bangsa (PKB). ${ }^{89}$ Then, in 2008-2012, she established Partai Kedaulatan Bangsa (PKB) and was entitled as the general chairman of the party ${ }^{90}$. As a Muslim activist, Yenny Wahid's tweets are an essential concern for the community. Her position is quite crucial in fighting for democracy in Indonesia, making her Twitter account in the spotlight. The map of Yenny Wahid's tweets is in the following chart:

Figure 3. Yenny Wahid's Tweets Conversation Map

\section{@yennywahid Tweets Mapping}

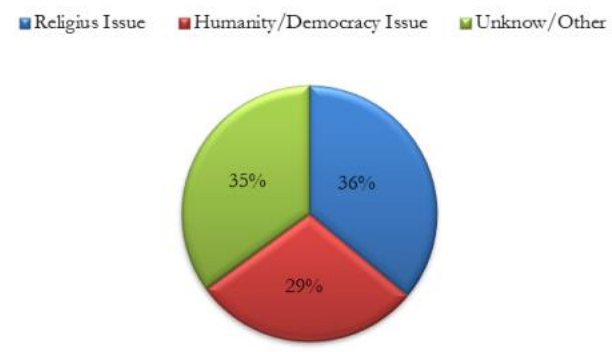

Based on Figure 3, it appears that Yenny Wahid's tweets were high on the topics of social education. $36 \%$ of her tweets were on religious education, and $29 \%$ of them were on democracy, Indonesia. $35 \%$ of the tweets were on various topics. Similar to Alissa, Yenny's top tweets on social education will be analyzed further based on the public response. It appears that Indonesian responded to Yenny Wahid's tweets well. Yenny's top tweet is when she showed her gratitude for Joko Widodo (b. 1961), better known as Jokowi, for sincerely wishing her mother, Shinta Nuriyah Wahid, a happy 70th birthday. In her tweets, Yenny wished that Jokowi will get the power to lead and organize the country. These tweets were re-tweeted 1,557 times and received 4,147 likes. Of the 1,557 re-tweets, $10 \%$ of them were analyzed further through people's cognitive level in understanding Yenny Wahid's tweets. The result showed that the Indonesians had

88 Ichwan Arifin, Kiai dan Politik; Studi Kasus Perilaku Politik Kiai dalam Konflik Partai Kebangkitan Bangsa (PKB) Pasca Muktamar II Semarang (Semarang: Universitas Diponegoro, 2008).

89 Ibid.

90 Ibid. 
various responses. Some of them wishing Shinta Nuriyah Wahid a happy birthday, but some others showed influential critics towards Jokowi's leadership. However, Some praised Jokowi for his sincerity.

Yenny's tweet shows that as a Muslim woman activist, she can shape public opinion about how to be a democratic person. This message is essential for Indonesia in conducting Indonesian political education. She is a well-known figure to Indonesians and thus has a significant role in influencing them. The use of twitter in communication as a digital literacy medium is effective in encouraging public opinion. These messages are part of social education for society. ${ }^{91}$ Yenny's educative message through twitter as a medium for digital literacy can help deliver a better Indonesia, following the philosophy of Indonesia, namely Pancasila. ${ }^{22}$

\section{Anita Hayatunnufus and MAFINDO Movement}

Gus Dur's third daughter is Anita Hayatunnufus or Anita Wahid. She focuses on the field of strengthening civil society. Anita is active in the Indonesian Anti-Slander Society (Masyarakat Anti Fitnah Indonesia/MAFINDO) and Hoax Community to ward off hoax in the country. ${ }^{93}$ This organization aims to make sure that the public does not believe hoax information easily. Following this, Anita was also active in preventing the spread of hoaxes during the 2019's presidential election. ${ }^{94}$

\footnotetext{
91 Johnson and others, "Twitter: a Tool for Communities of Practice," p. 23.

92 Jagad Aditya Dewantara and others, "Pancasila as Ideology and Characteristics Civic Education in Indonesia," International Journal for Educational and Vocational Studies, 1, 5 (2019), pp. 400-405.

93 Kabari, "VIDEO: Inayah Wahid Jangan Hanya Jadikan Milenial Sebagai Objek Semasa Pemilu" https://kabarinews.com/video-inayah-wahid-jangan-hanya-jadikanmilenial-sebagai-objek-semasa-pemilu/104375 (accessed on 22 October 2019).

94 Devina Halim, "Anita Wahid: Rata-rata 94 Hoaks per Bulan di Sepanjang Tahun 2018" https://nasional.kompas.com/read/2019/01/09/21482911/anita-wahid-ratarata-94-hoaks-per-bulan-di-sepanjang-tahun-2018 (accessed on 23 October 2019). See also Fitria Chusna Farisa, "Mafindo: Hoaks Terkait Pemilu 2019 Bertujuan Memupuk Kebencian" https://nasional.kompas.com/read/2019/08/20/20301231/mafindohoaks-terkait-pemilu-2019-bertujuan-memupuk-kebencian (accessed on 23 October 2019).
} 
Figure 4. Anita Wahid's Tweets Conversation Map

\section{(a) anitawahid Tweets Mapping}

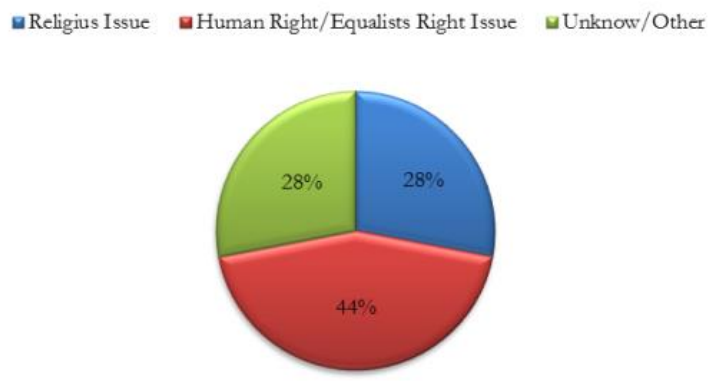

Based on Figure 4, Anita's tweets were the highest on the topic of civil society (44\%). Her tweets on religious education and others were $28 \%$. As explained earlier, Anita is active in the Indonesiana antislander and hoax society. Following a series of political elections in Indonesia, a lot of hoax news circulated in society. In this context, Anita takes a role to strive for shaping Indonesians towards an antihoax society.

It appears that based on Anita's tweets mapping, 44\% of her tweets, were on social education. Of her many tweets on social education, this study took one of her top tweets on this topic to be analyzed further based on the public response.

Indonesians responded to Anita's tweets well. Anita's top tweet was about her disappointment with the constitution, which she considered that it did not give power over the Corruption Eradication Commission (Komisi Pemberantasan Korupsi/KPK). Some assumed that the law could be easily revised. However, it turned out that law has come into force. Anita's top tweets were re-tweeted 1,943 times and received 2,250 likes. Of the 1,943 re-tweets, $10 \%$ of them were analyzed further through people's cognitive level in understanding Anita's tweets. The result shows that the Indonesians responded to the tweet differently. Some of them showed the same disappointment towards the government's decision to legally issuing the constitution. Some others blamed Anita because she seems supporting Jokowi, the current president of Indonesia, during the presidential election. Many criticized her and analyzed the background of the tweet.

The tweet is in line with Anita's active involvement in the Gusdurian Network, Indonesian Women Anti-Corruption, and the 
Indonesian Anti-Slander Society (MAFINDO). Anita's activity as a female activist is none other than fighting for human values, which are fundamental values taught by her father. ${ }^{95}$ Anita always uses her twitter account as a literacy medium to convey social education messages for the Indonesian people, including messages that are closely related to human rights. ${ }^{96}$ As an example of Anita's top tweets, discussed earlier, is her tweet on the KPK as a state institution that must protect citizens' rights. It teaches the value of honesty. Thus, twitter becomes an effective social media to convey messages. ${ }^{97}$

\section{Inayah Wulandari and the Human Rights Movement}

Gus Dur's fourth and youngest daughter is Inayah Wulandari, commonly called Inayah Wahid. She actively participated in the Positive Movement (PM) organization. 98 The organization was established in 2006 and focused on social issues, such as Indonesian workers (Tenaga Kerja Indonesia/TKI), human rights, etc. Through this organization, Inayah drives young people to spread the values of happiness and positive enthusiasm in life and to raise awareness that all elements in the society have the power to make positive changes and create peace. In 2016, Inayah was a member of Greenpeace Indonesia. ${ }^{99}$ Greenpeace is a non-governmental organization focusing on environmental issues. It has branches in more than 40 countries, and its headquarter is in Amsterdam, the Netherlands. According to Inayah, by joining Greenpeace, it enabled her to empower farmers while doing advocacy. If this effort is successful, the ideas of pluralism will be widely accepted.

Inayah is the unique daughter of Gus Dur. She is the only one who is involved in the world of art, especially theatre. She successfully played a role in a sitcom OK-Jek on Net TV. In the sitcom, Inayah's

\footnotetext{
95 Barton, Biografi Gus Dur, p. 20.

96 Ibid

${ }^{97}$ Johnson and others, "Twitter: a Tool for Communities of Practice," p. 26.

98 Budi Utomo, "Profil Inayah Wahid yang Digadang Jadi Menteri Jokowi" https://www.tagar.id/profil-inayah-wahid-yang-digadang-jadi-menteri-jokowi (accessed on 22 October 2019).

99 Dewi, "Perjuangan Inayah Wahid untuk Indonesia yang Lebih Baik, Seperti yang Diimpikan Sang Ayah" https://www.dewimagazine.com/news-art/perjuangan-inayahwahid-untuk-indonesia-yang-lebih-baik-seperti-yang-diimpikan-sang-ayah (accessed on 22 October 2019).
} 
role as an online motorcycle taxi driver. Inayah also actively participated in youth and culture organizations and activities. She has thousands of followers on her Twitter account. The map of Inayah Wahid's tweets conversation is in this following chart:

Figure 5 Inayah Wahid's Tweets Conversation Map

\section{@inayahwahid Tweets Mapping}

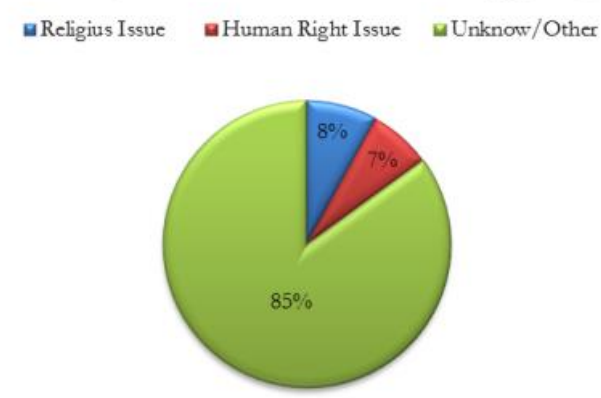

Inayah is unique compared to her sisters. She tends to be less active in social media, especially Twitter. She is more focused on the field of youth and culture. From her tweets, as can be seen in Figure 5, she did not discuss many social and religious issues. The number was $7 \%$ and $8 \%$ respectively. She used Twitter to discuss various topics (85\%). Inayah's Twitter account is different from her sister's. She rarely uses Twitter for socializing. Therefore, her Twitter does not appear bright as well as of her sisters. Her tweets were mostly in light conversations.

Based on Inayah's tweets mapping, it shows that 7\% of her tweets were on social education. Of her tweets on social education, this study took one of her top tweets on this topic to be analyzed further based on the public response.

It appears that Indonesians responded Inayah Wahid's tweets well. In her top tweets, Inayah was trying to clarify Yenny Wahid and Barisan Kader (Barikade) Gus Dur's statement, which showing support to Jokowi and Ma'ruf Amin during the presidential election. In her tweets, Inayah explained that Barikade Gus Dur was different from Gusdurian. Gusdurian network will always be neutral and, therefore, will not take aside. These tweets were re-tweeted 694 times and received 1,197 likes. Of the 694 re-tweets, $10 \%$ of them were analyzed further through people's cognitive level in understanding Inayah's 
tweets. The result showed that the Indonesians had various responses. Many of them thought that Gus Dur's family gave full support to Jokowi-Ma'ruf's side. There were many pros and cons, and many of them clearly stated that they would choose Prabowo and Sandi, the other presidential candidate pair. Some others followed the choice of Gus Dur's family.

As in the graphic, Inayah Wahid uses her Twitter to discuss various topics. One of the issues addressed in his Top Tweet is about human rights issues. No wonder the figure of Inayah Wahid has become a candidate to be the fourth minister of the president of the Republic of Indonesia. 100 Inayah always tries to convey social education through her tweets. Even though Inayah Wahid rarely uses Twitter when compared to her other siblings. However, all tweets delivered got a lot of responses from her followers.

Inayah is a female Muslim activist, and as the last daughter of Gus Dur, she gets a particular impression in the hearts of the Indonesian people. Her figure has a lot in common with her father. ${ }^{101}$ Thus, the character can influence and shape people's opinions through her tweets. Since she is also a well-known figure, the messages of social education can be accepted by the community. Social media, in the form of Twitter, is just right for her age. Most young people of Inayah's age use Twitter. ${ }^{102}$ Thus Inayah's mass base was the Indonesian youth group, especially youths of the Nahdlatul Ulama (NU).

\section{The Trend of Social Education through Digital Literacy of Abdurrahman Wahid's Daughters}

The result of clustering the community responses based on Anderson's taxonomy display in the form of the chart below. First, Alissa Wahid's tweets will be analyzed based on community's responses. Figure 6 shows the reactions to Alissa Wahid's social education tweets.

\footnotetext{
100 Nanda Febrianto, "Disebut Menteri Muda Jokowi, Ini Respons Inayah Wahid" https://www.tagar.id/disebut-menteri-muda-jokowi-ini-respons-inayah-wahid (accessed on 22 August 2019).

101 Barton, Biografi Gus Dur, p. 26.

102 Kementrian Komunikasi dan Informatika, "Indonesia Peringkat Lima Pengguna Twitter" https://kominfo.go.id/content/detail/2366/indonesia-peringkat-lima-pengguna-twitter/0/sorotan_media (accessed on 15 August 2019).
} 
Figure 6. Analysis Chart of the Responses to Alissa Wahid's Social Education Tweets Based on Anderson's Taxonomy

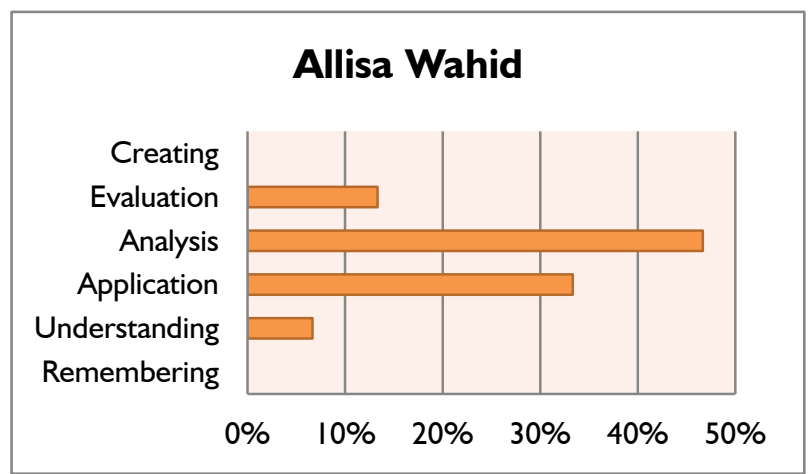

The Figure 6 shows that community's responses towards Alissa Wahid's social education tweets are in the level of analysis (46.67\%). It indicates that they could decipher the information, find assumptions, differentiate factual and hoax opinions and find causal relationships. ${ }^{103}$ It can be seen from their responses to Alissa's top tweet which was explained in the previous section, showing that most of them were able to analyze the background of the events conveyed by Alissa.

Furthermore, 33\% of those who reacted to Alissa's tweets are at the level of application, meaning that they have applied their concepts and principles to new situations that have never been given before. It can be seen from their responses to Alissa's top tweet which shows that they support the tweet because they feel sorry for the security forces. The level of society's cognitive understanding is considered reasonable since the percentage of responses in the level of evaluation is $13.33 \%$. A small number of criticisms of Alissa's top tweet showed that there is only a small proportion of them that are capable of evaluating information, including making decisions and policies.

Alissa is an activist of multiculturalism. Like her father, Alissa is known as a humanist figure and a defender of minorities in Indonesia. Even though she comes from the majority group, Alissa appreciates the plurality of the country. Alissa's personality makes it easy for the

103 Geoff Isaacs, Bloom's Taxonomy of Educational Objectives (Australia: University of Queensland, 1996), p. 2. 
majority of her Twitter followers to accept the social education that she conveyed.

Most of those who reacted to Alissa's tweets can understand the contents of her statements. It is because there is no response categorized as remembering. Their digital literacy ability through social education, conveyed by Alissa Wahid, is quite good. They can understand, apply, analyze, and evaluate the information. However, they have not reached the level of creating.

The subsequent analysis is on responses to Yenny Wahid's social education tweets.

Figure 7. Analysis Chart of the Responses to Yenny Wahid's Social Education Tweets Based on Anderson's Taxonomy

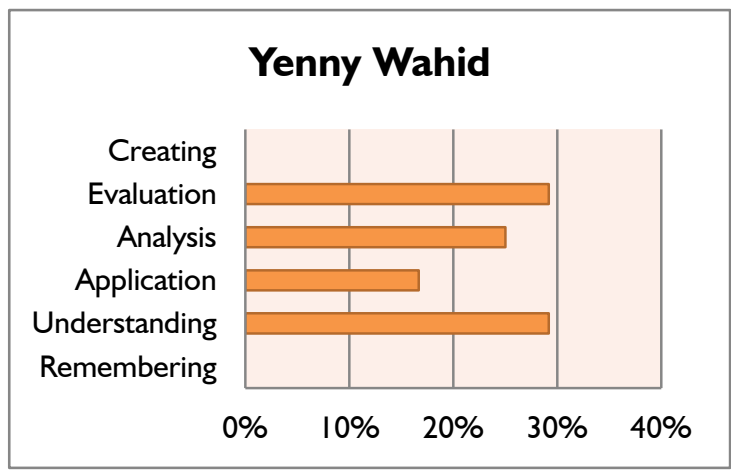

Based on Figure 7, society's level of cognitive understanding towards Yenny's social education tweets is considered excellent. Her activeness in voicing the issue of democracy through her tweets has been responded differently. The chart shows that there are $29.17 \%$ of the total of those who responded to Yenny's social education tweets are in the level of evaluation.

The relatively high number of people who are in the level of the assessment in Yenny's tweets compared to the three other Gusdur daughters indicates that they have a better understanding. It can be seen from their responses to Yenni's top tweets, where they show a reasonable criticism of Jokowi's leadership. However, some praised Jokowi's sincerity. The number of reactions on the level of analysis is $25 \%$, and those in the level of the application are only $16.67 \%$. Nevertheless, some tweets are considered in the category of low cognitive understanding, figuring $29.1 \%$. In addition, some others 
wished Shinta Nuriyah, Yenny's mother, a happy birthday. It shows that these people can apply their understanding of the message in their real life.

All of those who responded to Yenny's tweets could understand the contents of her statements. It can be seen from the chart that there was no response categorized as remembering. Their digital literacy ability through social education tweets, conveyed by Yenny Wahid, is quite well. It can be seen from how they understand, apply, analyze, and evaluate the information. However, they have not reached the level of creating.

The following analysis is on responses to Anita Wahid's tweets.

Figure 8. Analysis Chart of the Responses to Anita Wahid's Social Education Tweets Based on Anderson's Taxonomy

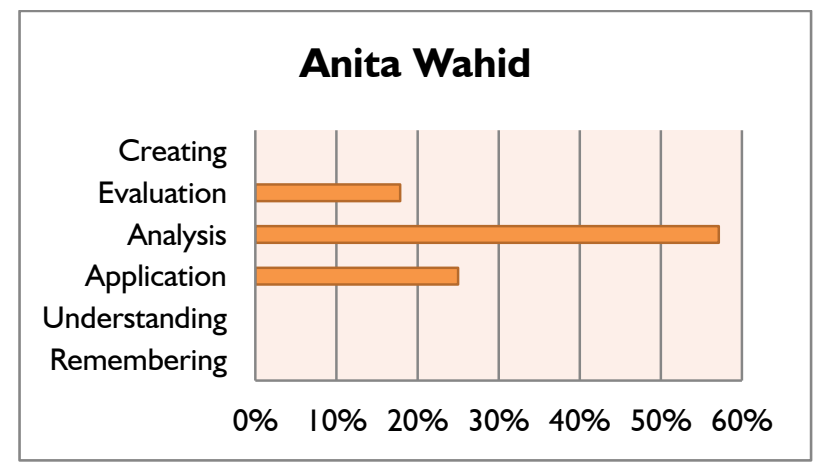

Based on Figure 8, society's level of cognitive understanding of Anita Wahid's social education tweets is considered excellent. It shows that the community's responses to Anita's social education tweets that are in the level of analysis are $57 \%$. It can be seen from their reactions to Anita's top tweet. Most of them tried to analyze Anita's context in writing her statement. Some of them even blamed Anita for being impressed to support Jokowi during the presidential election. The high level of analysis indicates that they are critical in responding to the issue.

Moreover, the number of reactions on the level of the application is $25 \%$. At this level, it indicates that they can apply their understanding of social education conveyed through Anita's tweets by using it in real terms. Some of them seem to support her statement. Those in the level of the evaluation are 18\%. They criticized the tweet 
and conveyed the background of why Anita delivered the statement. In this context, they are considered capable of assessing the benefits of something for a specific purpose based on clear criteria.

Most of them can understand the contents of Anita's tweets. There is no response, which is categorized as remembering and understanding. Their digital literacy ability through social education, conveyed by Anita Wahid, is quite good. How they understand, apply, analyze, and evaluate the information indicates the ability. However, they still have not reached the level of creating.

The subsequent analysis is on responses to Inayah Wahid's tweets.

Figure 9. Analysis Chart of the Responses to Inayah Wahid's Social Education Tweets Based on Anderson's Taxonomy

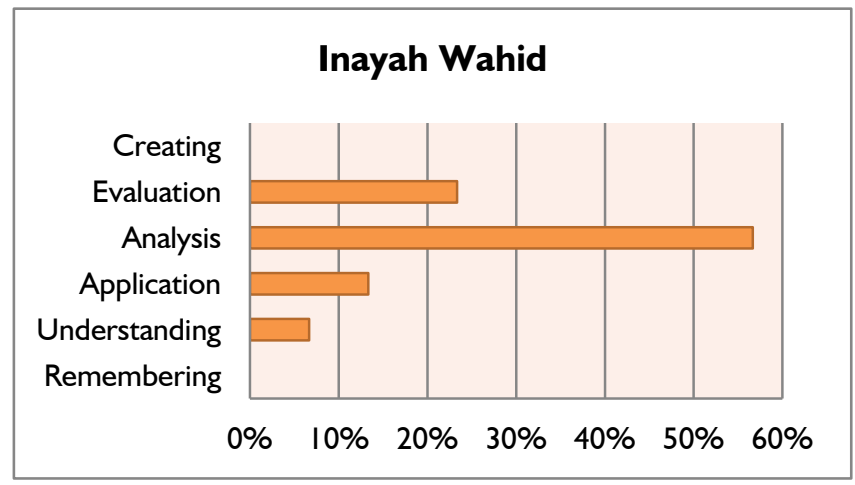

Based on Figure 9, it shows that there are $56.67 \%$ of the total of those who responded to Inayah's social education tweets are in the level of analysis. There are $23.3 \%$ of them that are in the level of evaluation. Therefore, the reactions are considered critical enough. Those who are in the levels of application and understanding are 7\% and $13.3 \%$, respectively. As previously explained, Inayah Wahid rarely uses Twitter to convey her aspirations. Based on the analysis, it shows that most of the cognitive abilities of the Indonesians who reacted to her top tweet are at the level of analysis. It can be seen in their comments. They reacted differently, expressing their opinions on the Jokowi-Ma'ruf and Prabowo-Sandi pairs.

Most of them can understand the contents of Inayah's tweets. There is no response categorized as remembering. Their digital literacy ability through social education, conveyed by Inayah, is quite good. 
They can understand, apply, analyze, and evaluate information, although they have not reached the level of creating.

Based on the explanation above, it proves that the average cognitive level of those who responded to social education tweets of Gus Dur's daughters is in the level of analysis and evaluation. It indicates that the Indonesian Muslim society are critical in responding to various social issues.

The level of analysis and evaluation in Anderson's taxonomy is at the cognitive level C4 and C5. Both of these cognitive levels show the right level of critical thinking skills. Similar to the findings of Zang and Kim; ${ }^{104}$ Becirovic et al., ${ }^{105}$ and Lucas, ${ }^{106}$ analytical skills and the ability to justify (evaluate) a context is part of the ability to think critically. In this globalization era, social media dramatically influences people's lifestyles. One indicator of human civilization development is technological progress. ${ }^{107}$ For the Indonesian people who are from diverse backgrounds, social media is very influential in educating society. ${ }^{108}$ Social education can be implemented in society. It requires a reasonably long and continuous process. ${ }^{109}$

The Twitter accounts of the four female Muslim activists are often referred by the Indonesian Muslims, especially the Gusdurian community. Their average cognitive ability in responding to the tweets of the four daughters of Gusdur can be seen in Figure 10.

104 Lili Zhang and Sukwoo Kim, "Critical Thinking Cultivation in Chinese College English Classes," English Language Teaching, 11, 8 (2018), pp. 159-64.

105 Senad Bećirović, Fatima Hodžić, and Amna Brdarević-Čeljo, "The Problems of Contemporary Education: Critical Thinking Development in the Milieu of High School Education," European Journal of Contemporary Education, 8, 3 (2019), pp. 469-82.

106 Kyle J. Lucas, "Chinese Graduate Student Understandings and Struggles with Critical Thinking: A Narrative-Case Study," International Journal for the Scholarship of Teaching and Learning, 13, 1 (2019), pp. 1-7.

107 McDougall, Readman, and Wilkinson, "The Uses of (Digital) Literacy Learning," p. 9 .

108 Wahid, Prisma Pemikiran Gus Dur, p. 3.

109 Kartono, Pendidikan Politik Sebagai Bagian dari Pendidikan, p. 5. 
Figure 10. Average cognitive abilities of Indonesian society in responding to the social education of Indonesian Muslim Female Activists

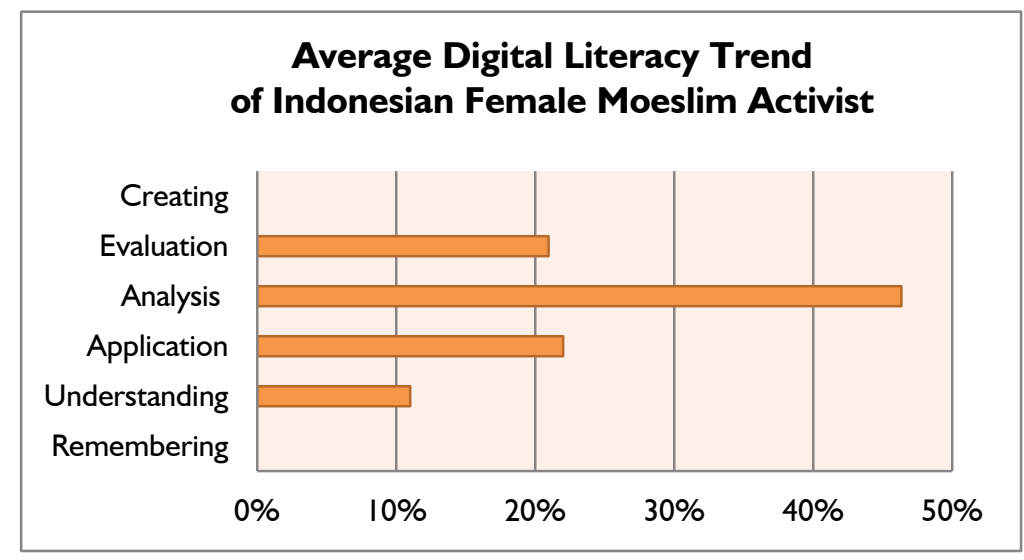

Based on Figure 10, it can be seen that most of the cognitive abilities of those who reacted to tweets of Gus Dur's daughters are at the level of Analysis (46.34\%), Evaluation (20.96\%), Application $(22 \%)$, and Understanding $(11 \%)$. It suggests that as female Muslim activists, Gus Dur's four daughters can trigger vital conversations. Likewise, their personality factor that can drive the community to changes. It is in line with the study of Belentsov et al., saying that influential figures such as public leaders could become informal teachers in social education. ${ }^{110}$ In this context, Gusdur's daughters have become teachers in social education by influencing and shaping attitudes or directing ideas to make a better society that upholds values of religion, multiculturalism, equality, democracy, and human rights.

This study differs from that of Neumann, ${ }^{111}$ Moss and Petrie, ${ }^{112}$ Duisenbayev et al., 113 and Barona and Carrió Neumann, Moss and Petrie, Duisenbayev et al., as well as Barona and Carrió. ${ }^{114}$ Neumann's research looks at aspects that lead to the failure of social education for

\footnotetext{
110 Belentsov and others, "The Organization of Social Education."

111 Neumann, "American Democracy in Distress," p. 9.

112 Moss and Pat Petrie, "Education and Social Pedagogy," p. 7.

113 Duisenbayev and others, "Study of Problems of Individual's Social Education," p. 12.

114 Barona and Carrió, "The Need of Education," p. 24.
} 
young people in the USA in implementing democracy. These young people do not have an idol or a central figure. Moss and Petrie's research focuses on the pragmatism of different perceptions of welfare in school-age children and the workforce. Duisenbayev et al. view that social education is the foundation for the development of social attitudes and character education. In addition, a research conducted by Barona and Carrió looks at how social education can inspire someone to become an animal lover.

Thus, the novelty of this research is in its argument, that an influential female figure in society can strengthen the process of character education. Likewise, the rapid development of technology and social media can increase the number of digital literacy users. Social education can be conveyed easily through the platform of Twitter. That Indonesian people are critical indicates that they are open-minded and can express their idea freely. It demonstrates the democratic ideals of Indonesia.

\section{Conclusion}

The role of Indonesian women activists represented by Gus Dur's daughters is quite significant in shaping public perception. It is formed by compelling messages on Twitter that contain social education. Gus Dur's daughters use Twitter as one of the platforms to convey their thoughts about religions, multiculturalism, equality, democracy, and human rights. Since they are public figures, they are able, to some extent, to influence society through their tweets.

Through their Twitter account, they share their perspectives on the current issues in society. Conversation in Tweeter may seem lighthearted, but it can convey social education messages. Based on Anderson's taxonomy, the public responses to the tweets of Gus Dur's daughters show that the public is so critical that they can express their ideas and can see a problem from various perspectives.] 


\section{References}

"Digital 2019: Global Digital Overview" https://datareportal.com/reports/digital-2019-global-digital-overview (accessed on 3 October 2019)

"Jaringan Gusdurian" http://www.gusdurian.net/id/jaringan-gusdurian/ (accessed on 22 October 2019)

"Number of Twitter Users in Indonesia from 2014 to 2019 (in Millions)." https://www.statista.com/statistics/490548/twitterusers-indonesia/ (accessed on 3 October 2019)

"Profil Zannuba Ariffah Chafsoh Rahman Wahid" https://m.merdeka.com/zannuba-ariffah-chafsoh-rahmanwahid/profil/ (accessed on 22 October 2019).

"Susunan Lengkap Pengurus LKKNU 2015-2020." https://www.nu.or.id/post/read/62263/susunan-lengkap-pengurus-lkknu-20152020 (accessed on 22 October 2019)

"Tweet Kemenangan Obama Jadi Tweet Terpopuler" https://www.liputan6.com/tekno/read/451332/tweet-kemenangan-obamajadi-tweet-terpopuler (accessed on 12 October 2019).

"VIDEO: Inayah Wahid Jangan Hanya Jadikan Milenial sebagai Objek Semasa Pemilu." https://kabarinews.com/video-inayah-wahidjangan-hanya-jadikan-milenial-sebagai-objek-semasa-pemi-

lu/104375 (accessed on 22 October 2019)

Abdullah, Ahmad Anis and Suhartini. "Meningkatkan Kemampuan Berpikir Kritis melalui Pembelajaran Statistika Berbasis Pendidikan Politik di Lingkungan Sekolah." Jurnal Gantang, 2, 1 (2017), pp. 1-9.

Alamsyah, Alamsyah. "Digital Literacy among Sriwijaya University Lecturers." Informasi, 47, 2 (2017), pp. 243-254.

Anderson, Lorin W., David R. Krathwohl, Peter W. Airasian, Kathleen A. Cruikshank, Richard E. Mayer, Paul R. Pintrich, and others. A Taxonomy for Learning, Teaching, and Assessing: A Revision of Bloom's Taxonomy of Educational Objectives. New York: Longman, 2013. 
Arifin, Ichwan. Kiai dan Politik; Studi Kasus Perilaku Politik Kiai Dalam Konflik Partai Kebangkitan Bangsa (PKB) Pasca Muktamar II Semarang. Semarang: Universitas Diponegoro, 2008.

Barona, Eduardo and Elena Carrió. "The Need of Education in Respect for Animals ( ERA ) as a Subject of the Social Education Degree at the University: An Overview Focused on Spain." Journal of Social Science Education, 15, 3 (2016), pp. 40-46.

Barton, Greg. Biografi Gus Dur; The Authorized Biography of Abdurrahman Wahid. Yogyakarta: LKiS Yogyakarta, 2003.

Bećirović, Senad, Fatima Hodžić and Amna Brdarević-Čeljo. "The Problems of Contemporary Education: Critical Thinking Development in the Milieu of High School Education." European Journal of Contemporary Education, 8, 3 (2019), pp. 469-82.

Belentsov, Sergei I., Valery Okulich-Kazarin, Svetlana V. Dyumina, and Alesya A. Kuznetsova. "The Organization of Social Education in Paul Natorp's Creativity." European Journal of Contemporary Education, 6, 4 (2017), pp. 656-63.

Buckingham, David. "Defining Digital Literacy: What Do Young People Need to Know about Digital Media?." Nordic Journal of Digital Literacy, 4 (2015), pp. 21-34.

Cahyono, Anang Sugeng. "Pengaruh Media Sosial terhadap Perubahan Sosial Masyarakat di Indonesia." Publiciana, 9, 1 (2016), pp. 14057.

Carley, Kathleen M., Momin Malik, Mike Kowalchuk, Jürgen Pfeffer, and Peter Landwehr. Twitter Usage in Indonesia. Pittsburgh: Institute for Software Research School of Computer Science Carnegie Mellon University, 2015.

Dewantara, Jagad Aditya, Ilham Fajar Suhendar, Rum Rosyid, and Thomy Sastra Atmaja. "Pancasila as Ideology and Characteristics Civic Education in Indonesia." International Journal for Educational and Vocational Studies, 1, 5 (2019), pp. 400-405.

Dewi. 'Perjuangan Inayah Wahid untuk Indonesia yang Lebih Baik, Seperti yang Diimpikan Sang Ayah" https://www.dewimagazine.com/news-art/perjuangan-inayah-wahid-untuk-indonesiayang-lebih-baik-seperti-yang-diimpikan-sang-ayah (accessed on 22 October 2019) 
Doyle, Dennis M. "Thomas Aquinas : Integrating Faith and Reason in the Catholic School." Catholic Education: A Journal of Inquiry and Practice, 10, 3 (2007), pp. 343-356.

Duisenbayev, Abay K., Mira R. Baltymova, Aktoty T. Akzholova, Gabit B. Bazargaliyev, and Arman Zh Zhumagaziyev. "Study of Problems of Individual's Social Education." International Journal of Environmental and Science Education, 11, 15 (2016), pp. 78997905.

Farid, Andyka Miftakhul. Implikatur-Implikatur Percakapan dalam Wacana Humor Gus Dur. Surakarta: Universitas Sebelas Maret, 2012.

Farisa, Fitria Chusna. "Mafindo: Hoaks Terkait Pemilu 2019 Bertujuan Memupuk Kebencian" https://nasional.kompas.com/read/2019/08/20/20301231/mafindo-hoaks-terkait-pemilu-2019bertujuan-memupuk-kebencian (accessed on 23 October 2019)

Febrianto, Nanda. "Disebut Menteri Muda Jokowi, Ini Respons Inayah Wahid" https://www.tagar.id/disebut-menteri-muda-jokowiini-respons-inayah-wahid (accessed on 15 August 2019)

Flavell, John H. "Theory of Mind Development: Retrospect and Prospect." Merrill-Palmer Quarterly, 50, 3 (2004), pp. 274-290.

Gilster. Digital Literacy. New York: Wiley, 1997.

Goodfellow, Robin. "Literacy, Literacies, and the Digital in Higher Education." Teaching in Higher Education, 16, 1 (2011), pp. 131144.

Halim, Devina. "Anita Wahid: Rata-rata 94 Hoaks Per Bulan di Sepanjang Tahun 2018" https://nasional.kompas.com/read/2019/01/09/21482911/anita-wahid-rata-rata-94-hoaks-per-bulan-di-sepanjang-tahun-2018 (accessed on 23 October 2019)

Haryanto, Agus Tri. "Riset: Ada 175,2 Juta Pengguna Internet di Indonesia" https://inet.detik.com/cyberlife/d-4907674/risetada-1752-juta-pengguna-internet-di-indonesia (accessed on 4 March 2020)

Hidayatullah, Ahmad Fathan. "Twitter Sebagai Media Dakwah." Teknoin, 22, 1 (2016), pp. 38-43.

Hoelman, Mickael B., Bona Tua Parlinggoman Parhusip, Sutoro Eko, Sugeng Bahagijo and Hamong Santono. Sustainable Development 
Goals-SDGs; Panduan untuk Pemerintah Daerah (Kota dan Kabupaten) dan Pemangku Kepentingan Daerah. Jakarta: Infid, 2016.

Isaacs, Geoff. Bloom's Taxonomy of Educational Objectives. Australia: University of Queensland, 1996.

Johnson, Mandy, Christie Bledsoe, Jodi Pilgrim and Hollis LoweryMoore. "Twitter: A Tool for Communities of Practice." SRATE Journal, 28, 1 (2019), pp. 61-75.

Juditha, Christiany. "Fenomena Trending Topic di Twitter: Analisis Wacana Twit \#Savehajilulung." Jurnal Penelitian Komunikasi Dan Pembangunan, 16, 2 (2018), pp. 138-154.

Kantaprawira, Rusadi. Sistem Politik Indonesia, Suatu Mode Pengantar Edisi Revisi. Bandung: Sinar Baru Algensindo, 2004.

Kartono, K. Pendidikan Politik Sebagai Bagian dari Pendidikan Orang Dewasa. Bandung: Mandar Maju, 2009.

Kementerian Komunikasi dan Informatika. "Indonesia Peringkat Lima Pengguna Twitter" https://kominfo.go.id/content/detail/2366/indonesia-peringkat-lima-pengguna-twitter/0/sorotan_media (accessed on 15 August 2019)

--------. "Kominfo: Pengguna Internet Di Indonesia 63 Juta Orang" https://www.kominfo.go.id/content/detail/3415/kominfopengguna-internet-di-indonesia-63-juta-orang/0/berita_satker (accessed on 3 October 2019)

------. "Pengguna Internet Indonesia Nomor Enam Dunia" https://kominfo.go.id/index.php/content/detail/4286/

Pengguna+Internet+Indonesia + Nomor + Enam + Dunia $/ 0 /$ soro tan_media (accessed 23 October 2019)

Kurnia, Novi, and Santi Indra Astuti. "Peta Gerakan Literasi Digital di Indonesia: Studi tentang Pelaku, Ragam Kegiatan, Kelompok Sasaran dan Mitra yang Dilakukan oleh Japelidi." Informasi, Jurnal Kajian Ilmu Komunikasi, 47, 2 (2017), pp. 149-66.

Kurniawati, Nia, Elis Homsini Maolida, and Agung Ginanjar Anjaniputra. "The Praxis of Digital Literacy in the EFL Classroom: Digital-Immigrant vs Digital-Native Teacher." Indonesian Journal of Applied Linguistics, 8, 1 (2018), pp. 28-37.

Lanham, Richard A. "Digital Literacy." Scientific American, 273, 3 (1995), pp. 198-200. 
Lucas, Kyle J. "Chinese Graduate Student Understandings and Struggles with Critical Thinking: A Narrative-Case Study." International Journal for the Scholarship of Teaching and Learning, 13, 1 (2019), pp. 1-7.

LW, Anderson, Krathwohl DR, Airasian PW, Cruikshank KA, Richard Mayer, Pintrich PR, and others. A Taxonomy for Learning, Teaching, and Assessing: a Revision of Bloom's Taxonomy of Educational Objectives. New York: Longman, 2001.

McDougall, Julian, Mark Readman, and Philip Wilkinson. "The Uses of (Digital) Literacy Learning." Media and Technology, 43, 3 (2018), pp. 263-79.

Minwer, Wail, Al Rabadi, and Rifqa Khleif Salem. "The Level of HighOrder Thinking and Its Relation to Quality of Life among Students at Ajloun University College." International Education Studies, 11, 6 (2018), pp. 8-21.

Moss, Peter and Pat Petrie. "Education and Social Pedagogy: What Relationship ?." London Review of Education, 17, 3 (2019), pp. 393405.

Muharir. "Arkeologi Pemikiran Pendidikan Islam; Studi Pemikiran Pendidikan Islam Abdurrahman Wahid." Jurnal Al-Muta'aliyah STAI Darul Kamal NW Kembang Kerang, 1, 1 (2017), pp. 25-52.

Neumann, Richard. "American Democracy in Distress: The Failure of Social Education." Journal of Social Science Education, 16, 1 (2017), pp. 5-16.

Nugroho, Nunung Dwi. Gerakan Gusdurian Sebagai Epistemic Community. Yogyakarta: Universitas Gajah Mada, 2013.

Pamungkas, Reza. "Keluarga Gus Dur Masih Sangat Berpengaruh" https://www.kompasiana.com/pinpol/5b9b6eaa677ffb65cc7d0 8f6/keluarga-gus-dur-masih-sangat-berpengaruh?page=all (accessed on 4 December 2019)

Papastephanou, Marianna. "Political Education in Times of Political Apathy and Extreme Political Pathos as Global Ways of Life." Educational Studies in Japan: International Yearbook, 13 (2019), pp. 81-95.

Phuapan, Piatip, Chantana Viriyavejakul and Paitoon Pimdee. "An Analysis of Digital Literacy Skills among Thai University 
Seniors." International Journal of Emerging Technologies in Learning, 11, 3 (2016), pp. 24-31.

Potter, W. James. "The State of Media Literacy." Journal of Broadcasting \& Electronic Media, 54, 4 (2010), pp. 675-696.

Prensky, Marc. Digital Natives, Digital Immigrants. In On the Horizon Lincoln: NCB University Press, 2001.

R, Jeko. I. "Pengguna Internet Indonesia Kuasai Media Sosial di 2015" https://www.liputan6.com/tekno/read/2164377/pengguna-internet-indonesia-kuasai-media-sosial-di-2015 (accessed on 3 October 2019)

Rizki, Rizal Abdul Aziz Hadi. Peran K.H. Abdurrabman Wabid/Gus Dur Pada Masa Reformasi (1998-2001). Bandung: UIN Sunan Gunung Djati, 2017.

Shariman, Tenku Putri Norishah Tenku, Norizan Abdul Razak, and Nor Fariza Mohd. Noor. "Digital Literacy Competence for Academic Needs: an Analysis of Malaysian Students in Three Universities." Procedia-Social and Behavioral Sciences, 69 (2012), pp. 1489-96.

Sianipar, Charlie M. "Jumlah Pengguna Twitter Indonesia Naik Pesat" https://www.tagar.id/jumlah-pengguna-twitter-indonesia-naik-pesat (accessed on 3 October 2019)

Sivrikaya, Mehmet Haluk. "An Analysis on Digital Literacy Level of Faculty of Sports Science Students." Asian Journal of Education and Training, 6, 2 (2020), pp. 117-21.

Tamburaka, Apriadi. Literasi Media: Cerdas Bermedia Khalayak Media Massa. Jakarta: Rajawali Press, 2013.

Traxler, John. "Digital Literacy: a Palestinian Refugee Perspective." Research in Learning Technology, 26 (2018), pp. 1-21.

Utomo, Budi. "Profil Inayah Wahid yang Digadang Jadi Menteri Jokowi" https://www.tagar.id/profil-inayah-wahid-yangdigadang-jadi-menteri-jokowi (accessed on 22 October 2019)

Wahid, Abdurrahman. Menggerakkan Tradisi: Esai-Esai Pesantren. Yogyakarta: LKiS Yogyakarta, 2001.

--------. Prisma Pemikiran Gus Dur. Yogyakarta: LKiS, 1999. 
Wahid Foundation. "Tentang Wahid Foundation" http://wahidfoundation.org/index.php/page/index/About-Us (accessed on 22 October 2019)

Wahid Instutute. "Tentang The WAHID Institute" http://www.wahidinstitute.org/wi-id/ (accessed on 15 October 2019)

Wenda, Werpen. "Tingkat Kesadaran Politik Pemilih Pemula dalam Pemilihan Umum Bupati dan Wakil Bupati Kabupaten Lanny Jaya Provinsi Papua." Jurnal Politico, 1, 3 (2013).

Widiyanto, Asfa. "Female Religious Authority, Religious Minority and the Ahmadiyya: The Activism of Sinta Nuriyah Wahid." Journal of Indonesian Islam, 9, 1 (2015), pp. 1-24.

Yildiz, Ezgi Pelin. "Opinions of Academicians on Digital Literacy: A Phenomenology Study." Cypriot Journal of Educational Sciences (CJES), 15, 3 (2020), pp. 469-478.

Zhang, Lili and Sukwoo Kim. "Critical Thinking Cultivation in Chinese College English Classes." English Language Teaching, 11, 8 (2018), pp. 159-64. 